\title{
Stimming behaviour in a 4-year-old girl with autism spectrum disorder
}

\author{
Ruziana Masiran
}

Department of Psychiatry, Universiti Putra Malaysia Fakulti Perubatan dan Sains Kesihatan, Serdang, Malaysia

\section{Correspondence to} Dr Ruziana Masiran, ruziana78m@yahoo.com

Accepted 8 February 2018

\section{DESCRIPTION}

A 4-year-old girl with autism spectrum disorder (ASD) developed a new behaviour of biting hard objects over the previous 6 months. The behaviour has not gotten better over time and she would always explore toys made of hard material (video 1 ) this way. Fortunately, she has not sustained any injury, choked on or swallowed these objects. She likes hot and spicy foods with textures. Her expressive language has only developed poorly.

'Stimming' or self-stimulatory behaviours, also known as stereotypic behaviours in ASD, usually come in the form of hand-flapping, body-rocking, pacing or repetition of words. However, chewing or biting non-edible objects is also common. There are a number of possibilities to explain this behaviour. First, stimming acts as a self-regulatory mechanism to help relieve anxiety, anger, fear and excitement as well as ward off meltdowns due to emotional insecurities. Second, problems in sensory processing integration is thought to cause an inability to receive and interpret sensory information. Parents of children with ASD reported more sensory symptoms, ${ }^{1}$ and disturbance in the prefrontal cortex and temporal lobe has been implicated. ${ }^{2}$

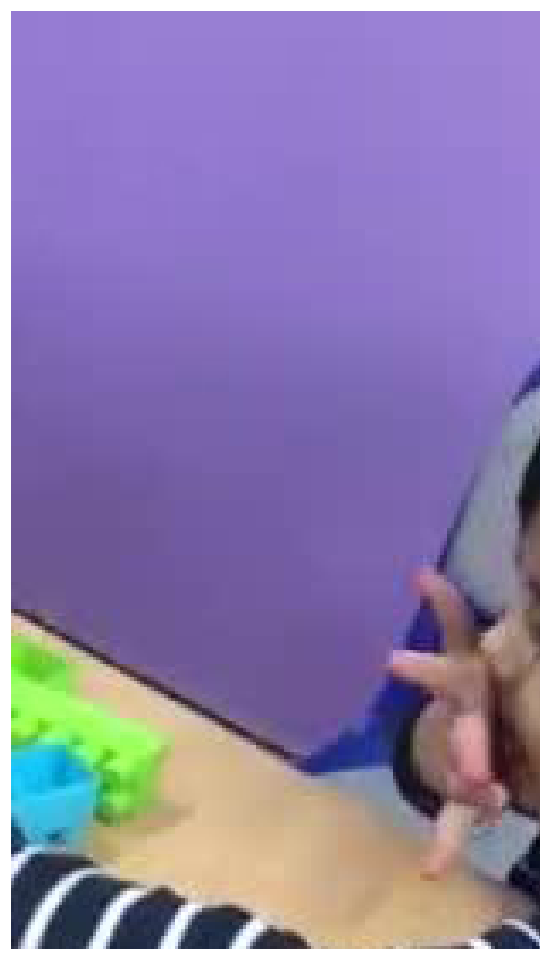

Video 1 The child instantly bites and puts hard toys she found in the room into her mouth.
Stimming helps these children to handle situations with overwhelming sensory input like being in a room that is too cold or too noisy. A child who bites, chews or sucks on non-edible objects is frequently hyposensitive to oral stimulation and thus requires him or her to continuously have something in his or her mouth, as this provides continuous oral stimulation. Having said that, stimming behaviours are only part of the challenges in ASD. Apart from understanding the behavioural issues at hand, carers must respond effectively to the needs of these children. Such is the aim of a framework established by The National Autistic Society, that is, the 'Structure, Positive approaches and expectations, Empathy, Low arousal, Links (SPELL)', which emphasises on providing the children with Structured activity and environment as well as using Positive approaches with positive expectations, as they are unable to achieve a certain level of skills due to their limited verbal communication and social interaction. Next, being Empathetic towards their emotional states is as essential as giving them a low-arousal environment with minimum noise, colour, odour, texture and lighting, which is helpful in promoting calm and reducing anxiety. Finally, providing Links encourages them to work with their families and even across wider support networks.

As much as stimming is serving as a tool to manage sensory and emotional input in children with ASD, it can undeniably be a source of distraction and fear to others. In addition, adults or children with autism who show these behaviours are

\section{Patient's perspective}

"She (the child) moved from being selective in her choice of foods to biting every hard object she stumbled upon. I am alright with this (behaviour) but worried about oral injury and what other people might think of her"

- from the mother of the child, during her clinic follow-up.

\section{Learning points}

Biting or chewing hard objects is part of stimming behaviours in autism spectrum disorder (ASD).

- Stimming is a self-regulatory mechanism for people with ASD to cope with anxiety.

- Sensory processing disintegration is an established cause for stimming behaviours. 
at risk for injury and are frequently marginalised. To reduce the biting behaviour, the child's mother was advised to substitute hard objects with safer alternatives like hard vegetables, chew toys and teething biscuits. In fact, a wide variety of 'stimming toys' have recently been invented and specially designed for children with ASD. Subsequently, her parents and therapists should work within her abilities with the right approach as outlined by the SPELL method.

Contributors RM has managed the patient and drafted this manuscript.

Funding This research received no specific grant from any funding agency in the public, commercial or not-for-profit sectors.

Competing interests None declared.
Patient consent Guardian consent obtained.

Provenance and peer review Not commissioned; externally peer reviewed.

(C) BMJ Publishing Group Ltd (unless otherwise stated in the text of the article) 2018. All rights reserved. No commercial use is permitted unless otherwise expressly granted.

\section{REFERENCES}

1 McCormick C, Hepburn S, Young GS, et al. Sensory symptoms in children with autism spectrum disorder, other developmental disorders and typical development: a longitudinal study. Autism 2016:20:572-9.

2 Marco EJ, Hinkley LB, Hill SS, et al. Sensory processing in autism: a review of neurophysiologic findings. Pediatr Res 2011:69:48R-54.

3 The National Autistic Society. Spell. 2016 http://www.autism.org.uk/about/strategies/ spell.aspx (cited 7 Feb 2018).

Copyright 2018 BMJ Publishing Group. All rights reserved. For permission to reuse any of this content visit

http://group.bmj.com/group/rights-licensing/permissions.

BMJ Case Report Fellows may re-use this article for personal use and teaching without any further permission.

Become a Fellow of BMJ Case Reports today and you can:

- Submit as many cases as you like

- Enjoy fast sympathetic peer review and rapid publication of accepted articles

- Access all the published articles

Re-use any of the published material for personal use and teaching without further permission

For information on Institutional Fellowships contact consortiasales@bmjgroup.com

Visit casereports.bmj.com for more articles like this and to become a Fellow 